\title{
Adhesion of Escherichia coli on to a series of poly(methacrylates) differing in charge and hydrophobicity
}

\author{
G. Harkes, J. Feijen and J. Dankert* \\ Department of Chemical Technology, University of Twente, PO Box 217, 7500 AE Enschede, The Netherlands. *Department of \\ Medical Microbiology. University of Amsterdam, Amsterdam, The Netherlarids \\ (Received 21 June 1990; accepted 13 September 1990)
}

\begin{abstract}
The adhesion of three Escherichia coli strains on to six poly(methacrylates) differing in hydrophobicity and surface charge was measured as a function of time under laminar flow conditions. Polymers used were poly(methyl methacrylate) (PMMA), poly(hydroxyethyl methacrylate) (PHEMA) and copolymers of MMA or HEMA with either $15 \%$ methacrylic acid (MAA) or $15 \%$ trimethylaminoethyl methacrylate-HCl salt (TMAEMA-CI). Bacterial and polymer surfaces were characterized by means of water contact angles and zeta potentials. Both the sessile drop contact angles and the zeta potentials of the bacterial surfaces were significantly different. No significant differences in the sessile drop contact angles of the polymer surfaces were observed. Using the Wilhelmy plate technique large contact angle hysteresis was observed for the different polymer surfaces. Surfaces of copolymers with MAA had more negative zeta potentials than those of the corresponding homopolymers. Surfaces of copolymers with TMAEMA-CI had positive zeta potentials. The highest numbers of adherent bacteria were found on materials with positive zeta potentials, irrespective of the bacterial strain used. Bacterial adhesion on to copolymers with MAA was less than on to the corresponding homopolymers. Bacterial equilibrium adhesion values correlate with the zeta potentials of the polymer surfaces $(r>0.85)$. On substrates with less negative zeta potentials high numbers of adhered bacteria were observed. Additionally, the equilibrium bacterial adhesion values could be related with receding contact angles of polymer surfaces with negative zeta potentials $(r>0.86)$. High equilibrium adhesion values were obtained for polymers with high contact angles. No correlation between the zeta potentials and contact angles of the bacteria with the adhesion values was found.
\end{abstract}

Keywords: Bacterial adhesion, poly(methacrylates), contact angle, zeta potential

Bacterial adhesion on to solid surfaces has been the subject of many studies in various areas, such as aquatic fouling research ${ }^{1.2}$, soil and plant ecology ${ }^{3-5}$, oral microbiology ${ }^{6-8}$ and biomaterial-associated infections 9.10 . Adhesion of bacteria on to inserted or implanted biomaterials is thought to be an essential step in the pathogenesis of implant-and medical device-associated infections ${ }^{10}$.

Urinary catheters are the most widely used devices in hospitals ${ }^{11}$ and urinary catheter-associated bacteriuria is the most frequently encountered hospital infection ${ }^{10}$. This infection, most often due to Escherichia coli ${ }^{10,12-14}$ is commonly derived from the patient's gastrointestinal tract flora, but the pathogenesis of catheter-associated bacteriuria is not clear. Nowadays bacteria will rarely reach the bladder along the internal lumen of the catheter because closed drainage systems are frequently used ${ }^{12}$. Most likely bacteria

Correspondence to Professor Dr J. Feijen gain entry into the bladder by migration along the outer surface of the catheter or along the peri-urethral epithelial cells ${ }^{12}$. The mechanisms by which bacteria reach the bladuer are still unclear. One mechanism may be that bacteria from the peri-urethral area spread along the catheter-urethra interface. Another mechanism may be that bacteria adherent on to the catheter are transferred to the bladder due to back and forth movements of the indwelling catheter in the urethra. This means that bacterial migration in the catheterized urethra is facilated by the presence of the catheter and that interaction of bacteria with the catheter may play an important role. The extent of bacterial adhesion on to the surface of various catheter materials may therefore be related to the incidence of urinary catheter-related bacteriuria.

In several studies attempts have been made to relate physico-chemical surface properties of bacteria as well as of solid surfaces to the ability of bacteria to adhere on to solid surfaces. Surface properties studied include hydrophobicity, 
surface free energy, surface charge and zeta potential. A variety of techniques are applied to determine bacterial hydrophobicity, such as the hexadecane/water partitioning ${ }^{15}$. hydrophobic interaction chromatography ${ }^{16}$, contact angle determination ${ }^{17,18}$ and salting out experiments ${ }^{19}$. Bacterial surface charge and zeta potential are determined by electrostatic interaction chromatography ${ }^{20}$ and micro-electrophoresis $^{21}$, respectively. Solid surfaces can be characterized by contact angle measurements, which can be used to estimate surface free energies and by micro-electrophoresis or streaming potential measurements ${ }^{22}$ to calculate the zeta potential.

We have studied the adhesion of three E.coli strains on to a series of poly(methacrylates) with different surface charge and hydrophobicity. Zeta potentials and contact angles of the bacteria and the polymer surfaces were determined in order to relate these properties with bacterial adhesion on to these surfaces. Time dependent adhesion experiments were done in a parallel-plate perfusion system placed in a vertical position to prevent bacterial sedimentation on to the polymer surfaces. The flow rate used was low in order to obtain laminar flow.

\section{MATERIALS AND METHODS}

\section{Bacteria}

Escherichia coli strains $0157 \mathrm{~K}-0161 \mathrm{~K}$ - and $0111 \mathrm{~K} 58$ were obtained from urine specimens collected from patients with bacteriuria. Identification was done using standard methods. Strains were biotyped ${ }^{23}$ and serotyped according to Orskov et al. ${ }^{24}$. Strains were maintained on Brain Heart Infusion (BHI) agar (Difco Laboratories, Detroit, MI, USA) slants at $4^{\circ} \mathrm{C}$ for $4 \mathrm{wk}$.

Strains were regularly applied to the API-2OE gallery (API Systems S.A., La Balme les Grottes, 38390 Montalieu, Vercieu. France) in order to confirm their identity.

For each experiment bacteria grown overnight in $\mathrm{BHI}$ broth at $37^{\circ} \mathrm{C}$ were harvested by centrifugation at $2000 \mathrm{~g}$ for $10 \mathrm{~min}$. Then bacteria were washed three times with $0.01 \mathrm{M} \mathrm{KCl}$ buffered with $8 \times 10^{-4} \mathrm{M} \mathrm{Na}_{2} \mathrm{HPO}_{4}$ and $2 \times 10^{-4} \mathrm{M} \mathrm{KH}_{2} \mathrm{PO}_{4}, \mathrm{pH} 7.4$. Finally, bacteria were resuspended in the same buffer to an optical density of 1.0 $\left(540 \mathrm{~nm}\right.$ ) representing approximately $10^{9}$ colony forming units (c.f.u.) per $\mathrm{ml}$, as determined by culturing and plate counting.

\section{Polymers and characterization of polymer surfaces}

Polymers were synthesized by radical polymerization of the corresponding monomers using 2,2'-azobis(methyl isobutyrate) as an initiator ${ }^{25-29}$. Methyl methacrylate (MMA) and trimethylaminoethyl methacrylate- $\mathrm{HCl}$ salt (TMAEMACl) were purchased from Polyscience Inc. Warrington. PA. USA. Methacrylic acid (MAA) and 2-hydroxyethyl methacrylate (HEMA) were purchased from Fluka Chemie $A G$. Buchs, Switzerland.

The methacrylate polymers and copolymers used in this study were: poly(methyl methacrylate) (PMMA), poly(hydroxyethyl methacrylate) (PHEMA) and copolymers of MMA and MAA, MMA and TMAEMA-Cl, HEMA and MAA, HEMA and TMAEMA-Cl. The copolymers had a molar ratio of $85 / 15$.

Polymer films were prepared either by dip coating (for the adhesion experiments) or by spin casting (for the streaming potential measurements) as described elsewhere ${ }^{25}$. Coatings of the polymers were made on glass slides
( $1 \times 3$ inch, thickness $1 \mathrm{~mm}$, Superior, Marienfeld, Bad Mergentheim, Germany), which were silanized with $n$ propylimethoxysilane (Polyscience) in case of PMMA and with $\gamma$-aminopropyltriethoxysilane (Janssen Chimica, Beerse, Belgium) in case of PHEMA and the negatively charged polymers. HEMA (co)polymers were cross-linked on to the glass slides using hexamethylene diisocyanate (Merck, Darmstadt, Germany). The polymer films were dried in vacuo at $60^{\circ} \mathrm{C}$ overnight.

\section{Determination of contact angles}

Advancing and receding contact angles of polymer surfaces were determined with the Wilhelmy plate technique. Dry polymer surfaces as well as surfaces pre-equilibrated in $0.01 \mathrm{M} \mathrm{KCl}$ buffered with $8 \times 10^{-4} \mathrm{M} \mathrm{Na}_{2} \mathrm{HPO}_{4}$ and

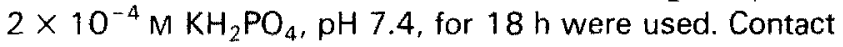
angles of uncharged polymers and of charged polymers were measured at $21^{\circ} \mathrm{C}$ using water and the buffer mentioned above, respectively.

Advancing water contact angles of polymer and bacterial surfaces were also determined using the sessile drop technique. Washed bacteria were collected on a cellulose acetate filter, pore size $0.45 \mu \mathrm{m}$ (Metricel GA-6, Gelman Sciences Inc., Ann Arbor, MI, USA). Uniform lawns of bacteria consisting of at least 50 layers of close packed bacteria were obtained. After a standard drying time of 20 min plateau contact angles ${ }^{17,30}$ were determined. Three different overnight cultures of each strain were prepared. From each culture two bacterial lawns were made. The mean contact angle of a strain was calculated from the values obtained from the six bacterial lawns.

\section{Zeta potentials}

The electrophoretic mobility of bacteria of the three strains was measured with a 500 Lazer Zee meter (PenKem, Bedford Hills, NY, USA) to calculate the zeta potential. Bacteria were resuspended in $0.01 \mathrm{M} \mathrm{KCl}$ buffered with $8 \times 10^{-4} \mathrm{M} \mathrm{Na}_{2} \mathrm{HPO}_{4}$ and $2 \times 10^{-4} \mathrm{M} \mathrm{KH}_{2} \mathrm{PO}_{4}, \mathrm{pH} 7.4$. Experiments were done three times with bacteria from different overnight cultures.

Streaming potentials of polymer surfaces in contact with the same buffer were obtained using an apparatus developed by van Wagenen and Andrade ${ }^{22}$ in which two polymer surfaces are placed parallel to each other. This was done for non-equilibrated surfaces as well as for surfaces pre-equilibrated in the buffer for $18 \mathrm{~h}$. Zeta potentials were calculated from the streaming potentials assuming that surface conductance is negligible.

\section{Bacterial adhesion}

Adhesion experiments were carried out with a perfusion system as described by Hogt et al ${ }^{31}$ at $37^{\circ} \mathrm{C}$. A flow rate of $60 \mathrm{ml} / \mathrm{h}$ resulting in a laminar flow with a Reynolds number of 1.5 was used. Each perfusion chamber contained one test polymer and PMMA as the reference polymer. After equilibration of the system with the adheison buffer $10.01 \mathrm{M}$ $\mathrm{KCl}$, buffered with $8 \times 10^{-4} \mathrm{M} \mathrm{Na}_{2} \mathrm{HPO}_{4}$ and $2 \times 10^{-4} \mathrm{M}$ $\left.\mathrm{KH}_{2} \mathrm{PO}_{4}, \mathrm{pH} 7.4\right)$ the bacterial suspension $\left(10^{9}\right.$ c.f.u. $\left./ \mathrm{ml}\right)$ was perfused for different time periods $(5,10,15,20,60$, 120,180 and $240 \mathrm{~min}$ ). Then the system was perfused for $30 \mathrm{~min}$ with the buffer to remove non-adherent bacteria. In order to fix adherent bacteria the system was perfused with $2 \%(\mathrm{w} / \mathrm{v})$ glutaraldehyde in buffer for $15 \mathrm{~min}$. Finally, the system was rinsed with water for $50 \mathrm{~min}$. After drying, the 
bacteria adherent on the polymer coatings were counted microscopically with a calibrated eyepiece. The number of adhering bacteria on to the test materials $\left(x_{i}\right)$ and the PMMA reference material $\left(y_{i}\right)$ were counted on eight $(i=1,2, \ldots 8)$ $0.01 \mathrm{~mm}^{2}$ areas which were $0.5 \mathrm{~cm}$ apart on the axial midline of the slides at a distance of 1.5 to $5.0 \mathrm{~cm}$ from the entrance of the chamber.

Mean numbers of adhering bacteria on to the test material $(X)$ after each perfusion period were calculated from:

$$
x=\frac{1}{8} \sum_{i=1}^{i=8} y_{i}^{x_{i}} \cdot y_{1}(i=1,2, \ldots 8)
$$

$V_{i}$ represents the mean number of adhering bacteria on to the corresponding PMMA area calculated from the number of adhering bacteria $\left(y_{i j}\right)$ determined in all $(j=1,2, \ldots n)$ experiments:

$$
y_{i}=\prod_{n}^{1} \sum_{i=1}^{i=n} y_{i j}
$$

The mean number of adhering bacteria on to PMMA for each perfusion period $(Y)$ was calculated from $y_{i}$ :

$$
Y=\frac{1}{8} \sum_{i=1}^{i=8} y_{i}
$$

Equilibrium adhesion values were obtained by a numerical least square fitting procedure of the data points with the following formula ${ }^{32,33}$ :

$$
n_{\mathrm{t}}=n_{\mathrm{e}}\left[1-\exp \left(\begin{array}{c}
-j_{0} \\
n_{\mathrm{e}} t
\end{array}\right)\right]
$$

where $n_{t}$ is the number of adhering bacteria at time $t, n_{e}$ is the number of adhering bacteria when equilibrium is reached and $j_{0}$ is the initial rate of adhesion. This formula was derived assuming reversible adhesion and a desorption constant which is independent of the bacterial coverage of the polymer surface. The initial rate of adhesion was obtained by a polynomial curve fit of the data points.

\section{RESULTS}

\section{Characterization of bacterial and polymer surfaces}

Contact angles $(\theta)$. Sessile drop contact angles $\left(\theta_{\mathrm{sd}}\right)$ of the bacterial surfaces of the three E.coli strains were slightly but significantly different. E.co/ $0157 \mathrm{~K}$ - is the most hydrophilic strain and $0111 \mathrm{~K} 58$ is the least hydrophilic strain (Table 1).

Water contact angles (sessile drop) of the six polymer surfaces varied between $67^{\circ}$ and $73^{\circ}$ (Table 1). These values were not significantly different. Advancing $\left(\theta_{a}\right)$ and receding $\left(\theta_{r}\right)$ contact angles of the non-equilibrated polymer surfaces determined by the Wilhelmy plate technique showed a wide variation from $61^{\circ}$ to $106^{\circ}$ and from $19^{\circ}$ to $58^{\circ}$, respectively. Advancing contact angles of the copolymers were always higher than those of the corresponding homopolymers, except for PMMA TMAEMA-Cl. As expected this polymer had a lower advancing contact angle than PMMA. Receding contact angles of the copolymers were lower than or equal to those of the corresponding homopolymers. For all surfaces a large contact angle hysteresis was observed. After equilibration of the surfaces in buffer a decrease of the advancing contact angles was found, except for PHEMA and PHEMA MAA. Also lower receding contact angles were obtained, except for PHEMA.

Zeta potentials (乡). Zeta potentiais of the bacterial strains and the polymer surfaces are shown in Table 2. Zeta potentials of the three E.coli strains were negative and varied widely. MAA containing copolymers had a more negative zeta potential than the corresponding homopolymers. Positive zeta potentials were measured for TMAEMA-CI containing copolymers. Equilibration in buffer for $18 \mathrm{~h}$ of the uncharged polymers and PHEMAMMAA had little or no effect on their zeta potentials, whilst the zeta potential of PMMA/MAA became less negative and of PHEMA TMAEMA-Cl less positive. The zeta potential of PMMA TMAEMA-Cl changed from positive to negative.

\section{Bacterial adhesion}

Numbers of bacteria adhering on to different polymer surfaces as a function of time are shown in Figures 1-7. Figure 1 shows the number of adhering bacteria of the three

\begin{tabular}{|c|c|c|c|c|c|}
\hline \multirow[b]{2}{*}{ Surface } & \multicolumn{3}{|c|}{ Non-cquilibrated surfaces ${ }^{A}$} & \multicolumn{2}{|c|}{ Pre equilibrated surfaces ${ }^{b}$} \\
\hline & $\theta_{\text {SN }}\left({ }^{\circ}\right)$ & $\theta^{H}$ & $H^{r}$ & $n_{1}$ & $\theta_{r}$ \\
\hline \multicolumn{6}{|l|}{ Bacteria: } \\
\hline Ecoli $0111 \mathrm{k} 58$ & $29.0+1.4$ & & & & \\
\hline $0157 K-$ & $17.7+0.6$ & & & & \\
\hline $0161 \mathrm{~K}$ & $24.5-7.8$ & & & & \\
\hline \multicolumn{6}{|l|}{ Polymers: } \\
\hline PMMA & $71.8-2.5$ & $83.7 \cdot 2.7$ & $58.0 \cdot 1.2$ & $75.8 \cdot 0.6$ & $35.9+8.0$ \\
\hline PHEMA & $72.7 \cdot 3.2$ & $61.1 \cdot 4.1$ & $23.3 \cdot 2.3$ & $72.7 \cdot 0.5$ & $27.3 \cdot 3.6$ \\
\hline PMMA MAA & $70.0+1.7$ & $90.9 \cdot 3.5$ & $27.6 \cdot 1.1$ & $83.5 \cdot 1.5$ & $23.3+4.6$ \\
\hline PMMA TMAEMA-CI & $67.5+2.3$ & $80.8 \cdot 2.0$ & $18.6 \cdot 4.5$ & $77.0+1.6$ & $16.8+2.2$ \\
\hline PHEMA/MAA & $72.2+3.0$ & $70.9-5.6$ & $22.6 \cdot 3.9$ & $89.8 \cdot 1.8$ & $7.2+2.2$ \\
\hline PHEMA TMAEMA-Cl & $70.5-3.1$ & $106.1-6.9$ & $23.0+2.0$ & $100.6+2.5$ & $20.5+1.3$ \\
\hline
\end{tabular}
E.colistrains on to PMMA $(Y)$ as a function of exposure time.

Table 1 Water contact angles of bacteria determined with the sessile drop method and of polymer surfaces determmed with the sessile drop method and the Wilhelmy plate technique

a Measurements after drying in vacuo at $60^{\circ} \mathrm{C}$ overnight

${ }^{b}$ Pre-equilibration in $0.01 \mathrm{M} \mathrm{KCl}$, buffered with $8 \times 10^{4} \mathrm{M} \mathrm{Na}_{2} \mathrm{HPO}_{4}$ and $2 \times 10^{4} \mathrm{M} \mathrm{KH}_{2} \mathrm{PO}_{4}, \mathrm{pH}_{7.4}$ for $18 \mathrm{~h}$

${ }^{c}$ Mean values of three determinations - s.d. 
Table 2 Zeta potentials ( $)$ ) of bacteria and polymer surfaces

\begin{tabular}{|c|c|c|}
\hline \multirow[b]{2}{*}{ Surface } & \multicolumn{2}{|c|}{ Zeta potentials in $\mathrm{mV}^{\mathrm{a}}$} \\
\hline & $t=0$ & $\begin{array}{l}\text { After pre-equilibration } \\
(t=18 \mathrm{~h})\end{array}$ \\
\hline \multicolumn{3}{|l|}{ Bacterı: } \\
\hline $\begin{array}{c}\text { Ecoli } 0111 \mathrm{~K} 58 \\
0157 \mathrm{~K}- \\
\\
0161 \mathrm{~K}-\end{array}$ & $\begin{array}{r}-2.8+2.2 \\
-8.9+2.6 \\
-33.8+5.3\end{array}$ & \\
\hline \multicolumn{3}{|l|}{ Polymers: } \\
\hline PMMA & $-13.6+0.6$ & $-15.8+1.1$ \\
\hline PHEMA & $-13.4+1.3$ & $-13.4+1.1$ \\
\hline PMMA'MAA & $-36.7+2.7$ & $-28.7+2.4$ \\
\hline PMMA TMAEMA-CI & $+16^{b}$ & $-4.6+3.3$ \\
\hline PHEMA MAA & $-23.0+0.4$ & $-21.7+0.5$ \\
\hline PHEMA TMAEMA-Cl & $+9.8+0.7$ & $+5.8+0.9$ \\
\hline
\end{tabular}

${ }^{a}$ Mean values of three measurements $+s . d$.

bThis zeta potential changes too fast to be measured correctly

There is a significant difference in the adhesion characteristics of the three strains. Strain $0161 \mathrm{~K}$-with the most negative zeta potential had the highest initial adhesion rate and equilibrium adhesion value. Strain $0111 \mathrm{~K} 58$ with the least negative zeta potential had the lowest initial adhesion rate and equilibrium adhesion value.

Figures 2 and 3 show the number of adherent bacteria $(X)$ of strain $0111 \mathrm{~K} 58$ on to PMMA (co)polymers and PHEMA (co)polymers, respectively. The highest numbers of adherent bacteria were observed on the positively charged

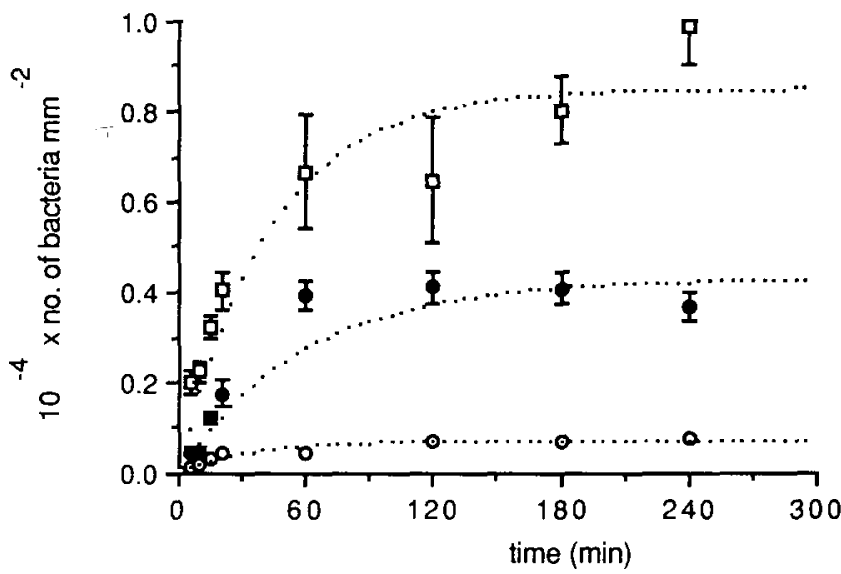

Figure 1 Adhesion of the three E.coli strains on to PMMA as a function of time. Dotted lines represent the curves based on fitting the data points according to Equation (4). Bars indicate 95\% confidence limits. $0,0111 \mathrm{~K} 58$ , $0157 K-;, 0161 K$

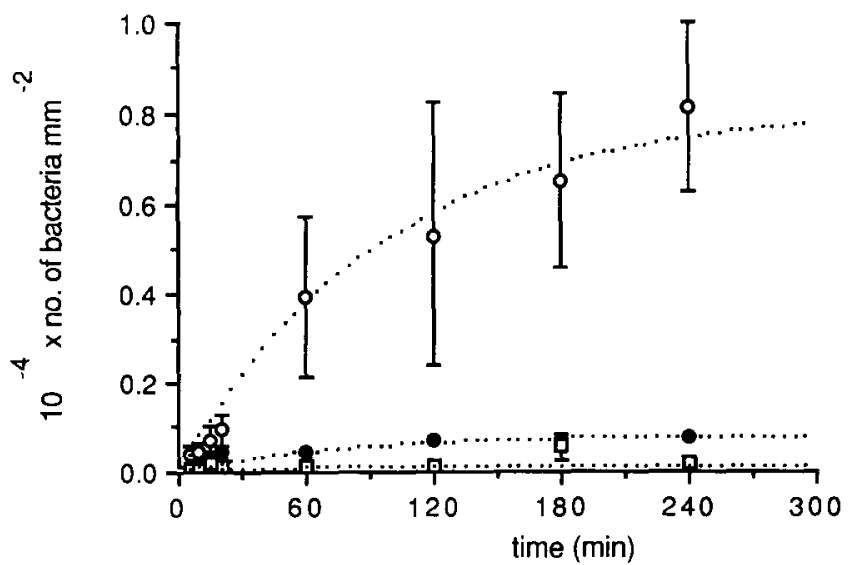

Figure 2 Adhesion of E.coli $0111 K 58$ on to MMA (co)polymers as a function of time. O, PMMA/TMAEMA-Cl; ๑, PMMA; [, PMMA/MAA

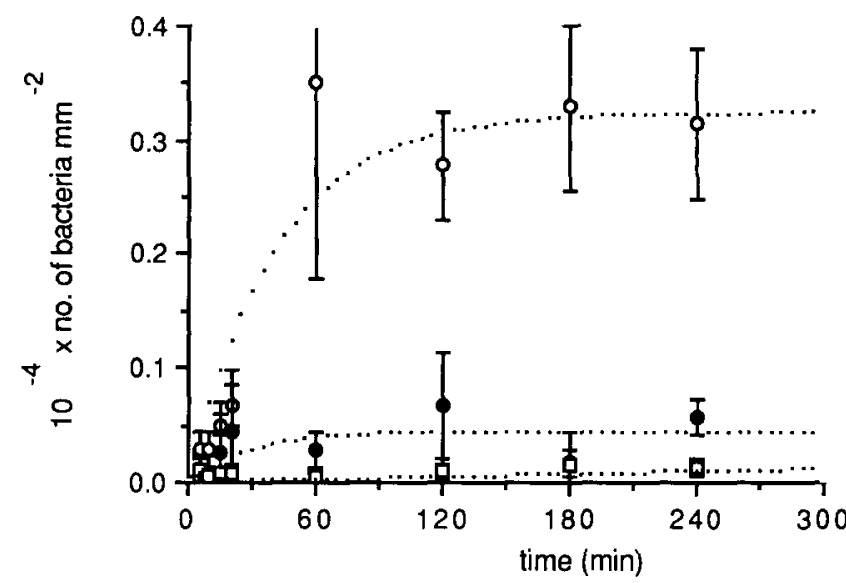

Figure 3 Adhesion of E.coli $0111 K 58$ on to HEMA (co)polymers as a function of time. O, PHEMA/TMAEMA-Cl; - PHEMA; $\square$, PHEMA/MAA.

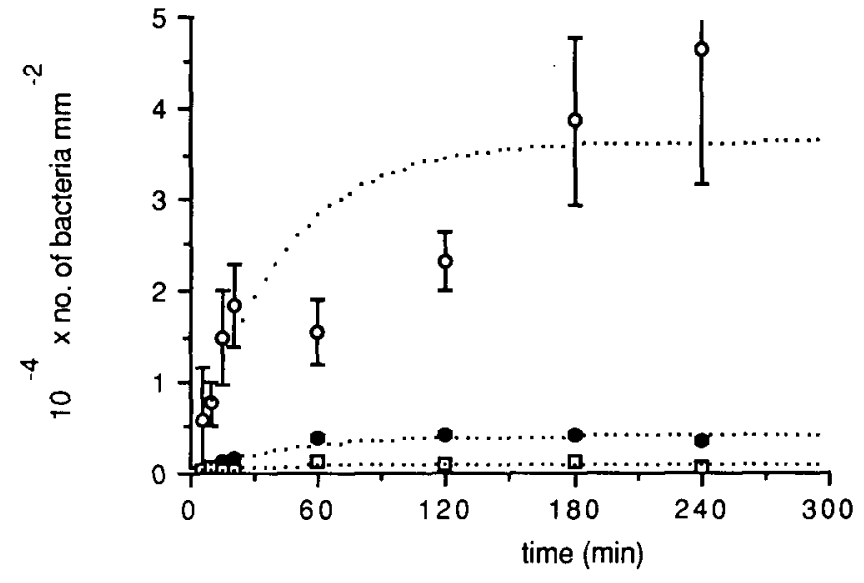

Figure 4 Adhesion of E.coli $0157 K$-on to MMA (co)polymers as a function of time. O. PMMA/TMAEMA-Cl; - PMMA: 口, PMMA/MAA

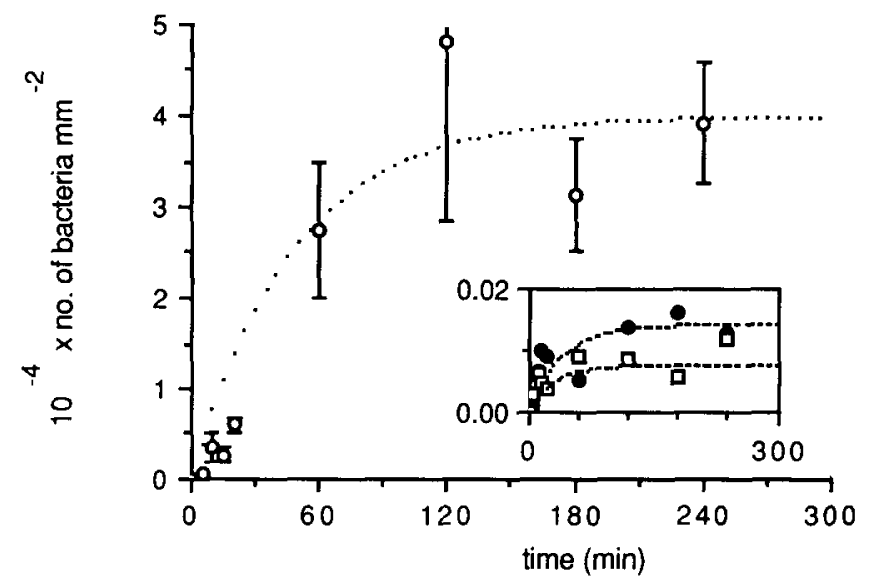

Figure 5 Adhesion of E.coli 0157K- on to HEMA (colpolymers as a function of time. For reasons of convenience error bars are not given in the inset. O, FHEMA TMAEMA-CI;, PHEMA; $\square$, PHEMA/MAA.

surfaces PMMA/TMAEMA-Cl (Figure 2) and PHEMA TMAEMA-Cl (Figure 3). On the negatively charged surfaces PMMA/MAA (Figure 2) and PHEMA/MAA (Figure 3), lower numbers of adherent bacteria were found than on the corresponding homopolymers PMMA (Figure 2) and PHEMA (Figure 3). Similar findings were obtained for strain $0157 \mathrm{~K}$ (Figures 4 and 5) and strain 0161K-(Figures 6 and 7).

It appeared that strain $0111 \mathrm{~K} 58$ gave the lowest equilibrium adhesion values for all polymer surfaces, except for PHEMA (Table 3). Strain O161K-gave the highest equilibrium adhesion values, except for the two positively 


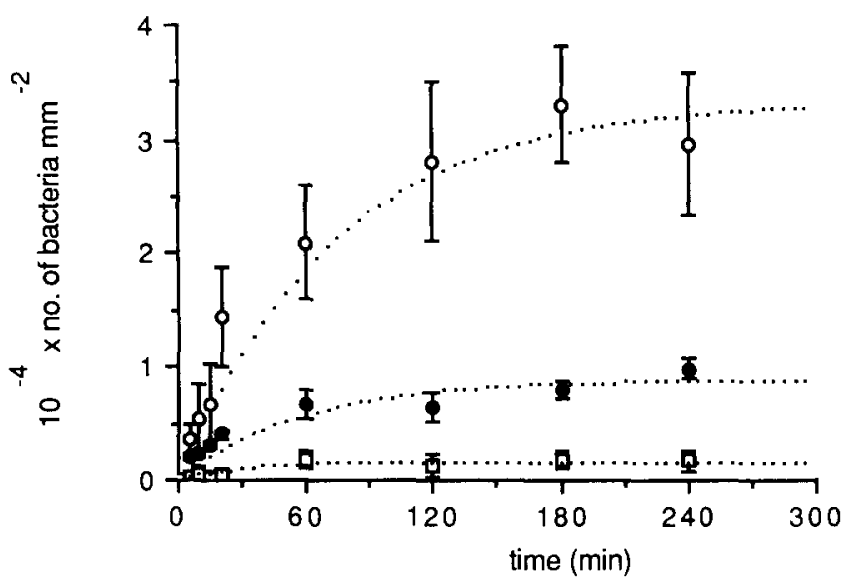

Figure 6 Adhesion of E.coliO161K-on to MMA /colpolymers as a function of time, O, PMMA/TMAEMA-Cl; - PMMA; $],$ PMMA/MAA.

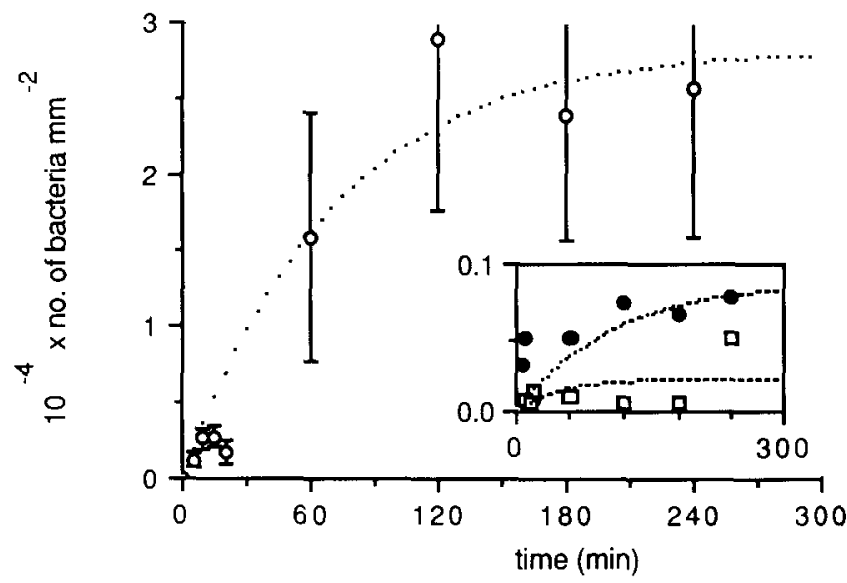

Figure 7 Adhesion of E.coli O161K- on to HEMA (co)polymers as a function of time. P. PHEMA/TMAEMA-Cl; O, PHEMA; $\square$, PHEMA/MAA.

charged surfaces. On these surfaces adhesion values for strain $0157 \mathrm{~K}$ - were highest.

\section{Discussion}

The DLVO theory can be used to describe the long range interactions between bacteria and solid surfaces ${ }^{34}$. Two additive forces play a role in this theory: London-van der Waals forces and electrostatic forces. The zeta potentials of both the bacterium and the solid surface are the main factors in the electrostatic forces. When the two zeta potentials have the same sign the electrostatic force will be repulsive. This repulsive force will be higher when the product of the zeta potentials of the bacterium and the polymer surface is higher. When these zeta potentials are also involved in the short-range interactions in principle less bacterial adhesion will occur when higher zeta potentials of the same sign are involved.

Table 3 Equilibrium adhesion values of E.coli strains on to various polv(methacrylates)

\begin{tabular}{lccc}
\hline & \multicolumn{2}{c}{ Numbers of adhering bacteria per $\mathrm{mm}^{2}\left(\times 10^{-3}\right)$} \\
\hline & E.coli $0111 \mathrm{~K} 58$ & E.coli $0157 \mathrm{~K}-$ & E.coli $0161 \mathrm{~K}-$ \\
\hline PMMA & & 4.1 & 8.9 \\
PHEMA & 0.8 & 0.1 & 0.9 \\
PMMA MAA & 0.5 & 1.1 & 1.7 \\
PMMATMAEMA-Cl & 0.2 & 36.3 & 33.4 \\
PHEMA MAA & 0.1 & 0.1 & 0.2 \\
PHEMA TMAEMA-Cl & 3.2 & 39.9 & 28.2 \\
\hline
\end{tabular}

Zeta potentials of the three bacterial strains used in this study varied from -2.8 to $-33.8 \mathrm{mV}$. Various authors have tried to relate the zeta potentials of bacteria to the number of adherent bacteria on to solid surfaces. Van Loosdrecht et al. ${ }^{35}$ observed no correlation between the electrophoretic mobility of several bacterial species and the bacterial adhesion on to negatively charged polystyrene. In contrast, Weerkamp et al ${ }^{8}$ reported that gram-positive bacteria with a small negative zeta potential adhered to a larger extent to enamel and dentin than bacteria with a more negative zeta potential. Relatively few studies on hacterial adhesion on to positively charged surfaces are known from the literature ${ }^{31.36,37}$. In these three studies a higher adhesion number of adherent cells was found on positively charged surfaces than on uncharged surfaces. Our results also showed that a very high number of adherent bacteria was found on to positively charged surfaces (PMMA) TMAEMA-Cl and PHEMA-TMAEMA-Cl) when compared to the number of adherent bacteria on to uncharged and negatively charged surfaces. Strains $0157 \mathrm{~K}$ - and $0161 \mathrm{~K}$ adhered to a much greater extent on to the positive charged surfaces than strain $0111 \mathrm{~K} 58$ which has the least negative zeta potential. Hogt et al..$^{31}$ suggested that adhesion of staphylococci on to positively charged surfaces is diffusion limited. The initial adhesion of the strains $0157 \mathrm{~K}$ - and $0161 \mathrm{~K}$ - is also probably diffusion limited, because no energy barrier is present between the polymer surface and the bacterium. This assumption is supported by the calculated initial deposition rates of the bacteria using the Smoluchowski-Levich equation ${ }^{32,38}$. The calculated initial deposition rate is in the same order of magnitude as the experimental initial rates of adhesion obtained for these strains on to PMMA/TMAEMA-Cl and PHEMA TMAEMA$\mathrm{Cl}^{39}$. The initial rate of adhesion of strain $0111 \mathrm{~K} 58$ with a zeta potential of $-2.8 \mathrm{mV}$ on to these surfaces is much lower than for the other two strains and therefore most likely not diffusion limited. Assuming that in all cases equilibrium was reached, the low number of adherent bacteria of strain $0111 \mathrm{~K} 58$ indicates that the primary minimum for this strain is less negative than for the other two strains ${ }^{40}$.

The adhesion of the three E.coli strains on to the uncharged and negatively charged surfaces with a negative zeta potential seems to have reached an equilibrium during the exposure time period of $4 \mathrm{~h}$ used in this study. Because in the adhesion experiments a buffer with a low salt concentration was used the occurrence of a secondary minimum low enough to trap bacteria, is very unlikely $y^{34,41}$. Therefore the depth of the primary minimum will determine the number of adherent bacteria. The number of adherent bacteria of strain $0161 \mathrm{~K}$ - on these surfaces was always higher than for the other two strains whilst strain $0161 \mathrm{~K}$. has the most negative zeta potential. Therefore such a finding was not expected. This may indicate that bacteria do not have a homogeneous surface structure. The adhesion of E.coli may be affected by the presence of flagellae and pili which may have a different (local) zeta potential than the overall zeta potential of bacteria measured by means of electrophoresis.

When the equilibrium adhesion values of the bacteria for the MMA and HEMA (co)polymers are plotted against their zeta potentials (Figure 8 ) a linear relationship with a reasonable correlation coefficient $(r>0.85)$ was found for all three bacterial strains. As expected a higher number of adherent bacteria was found on polymer surfaces with a less negative zeta potential. It was also observed that negatively charged copolymer surfaces gave always smaller numbers 


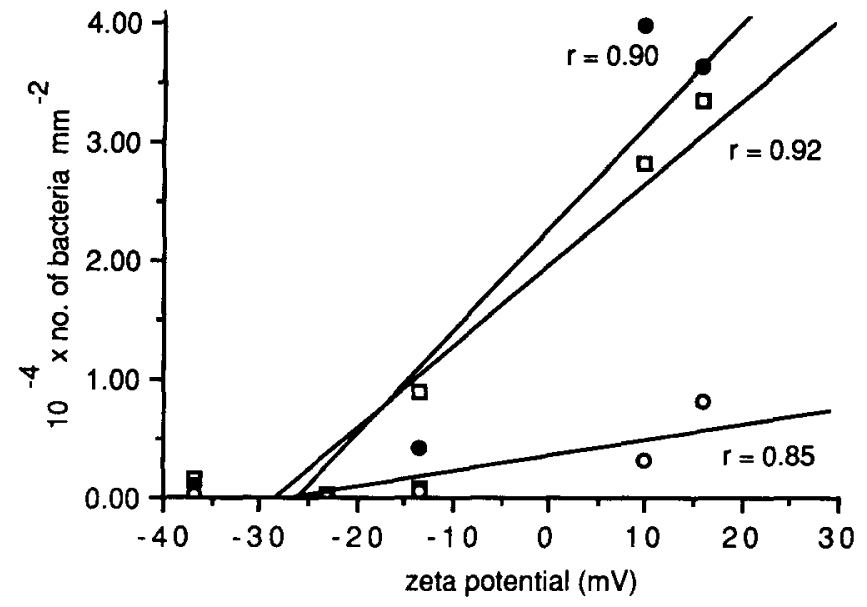

Figure 8 Equilibrium adhesion values against zeta potential of MMA and HEMA /colpolymers. 0, 0111K58; 0, 0157K-; $\square, 0161 \mathrm{~K}$ -

of adherent bacteria than the corresponding homopolymers. This indicates that for this series of polymers the zeta potential of the polymer surface is predictive for bacterial adhesion. However, the zeta potential of the bacterium could not be directly correlated with the number of adherent bacteria.

When only hydrophobic interactions between the bacterium and the solid surface are considered, a high number of adherent bacteria is expected for bacteria with a high contact angle. A high number of adherent bacteria may also be found on substrates with a high contact angle. Because hydrophobic interactions can only occur when water molecules are removed from the surfaces of both bacteria and solid substrate it is likely that the receding contact angle is most relevant to obtain insight into such a mechanism of the bacterial adhesion process. However, there is no method available to measure receding contact angles on bacterial surfaces as far as we know.

Contact angles of the three E.coli strains used in this study (Table 1) are not different from those found in other studies $^{18,42}$. Various attempts have been made to relate the contact angle of bacteria with the number of adherent bacteria on to solid substrates. Conflicting results of such studies are available in literature. Van Loosdrecht et al. ${ }^{42}$ has found a correlation between contact angles on bacteria (varying from $16^{\circ}$ to $70^{\circ}$ ) and their adhesion on to negatively charged polystyrene disks. Bacteria with a high contact angle adhered to a greater extent to these disks. Using a three-dimensional plot $^{35}$ they found that the electrophoretic mobility of the bacteria with a high contact angle was not associated with the adhesion value. In contrast, when the contact angle of the bacterial strain was rather low the influence of the electrophoretic mobility was much more pronounced resulting in high adhesion values for bacteria with a low electrophoretic mobility. Absolom et al. ${ }^{18}$ found high adhesion values for five bacteria on to substrates with high contact angles. Others ${ }^{7,32}$ did not find a relationship between contact angles of bacteria and numbers of adherent bacteria on to various substrata. In our study we found no correlation between the contact angles of bacterial surfaces and the ability of E.coli to adhere on to various polymer surfaces.

The contact angles of the polymer surfaces (Tab/e 1) determined with the Wilhelmy plate technique were rather similar with those obtained from previous experiments in our laboratory ${ }^{25}$. Sessile drop contact angles of the various polymer surfaces were not significantly different. Although contact angles determined with the sessile drop method have an advancing character, they do not correlate with the advancing contact angles obtained with the Wilhelmy plate technique. An explanation for this fact may be that with the Wilhelmy plate technique a dynamic contact angle is measured whereas with the sessile drop method a static contact angle is obtained. Pringle and Fletcher ${ }^{1}$ found a relation between sessile drop contact angles of various substrates (varying from $0^{\circ}$ to $110^{\circ}$ ) and adhesion values of four different kinds of bacteria. The highest number of adherent hacteria was observed on materials with contact angles between $65^{\circ}$ and $90^{\circ}$. Absolom et al. ${ }^{18}$ found a linear relationship between sessile drop contact angles of various polymers (varying from $24^{\circ}$ to $110^{\circ}$ ) and the adhesion of five different kinds of bacteria, but Busscher ${ }^{30}$ found no relation at all between contact angles of polymer substrates (varying from $58^{\circ}$ to $110^{\circ}$ ) and bacterial adhesion. In this study also no relation between the advancing contact angle of the substrates either determined with the sessile drop method or with the Wilhelmy plate technique and the bacterial adhesion on to these polymer surfaces was found. However, plotting the equilibrium hacterial adhesion values against the receding contact angles of the polymer surfaces with a negative zeta potential gave a linear relationship with a reasonable correlation coefficient $(r>0.86)$ for the three bacterial strains used (Figure 9). A high number of adherent bacteria was observed on polymer surfaces with high receding contact angles. This correlation was not found for polymer surfaces with a positive zeta potential indicatiny that the positive charge of the substrate plays a far more important role than hydrophobic interactions in the process of bacterial adhesion on to polymer surfaces.

It has to be emphasized that surface characteristics of polymer surfaces as contact angle and zeta potential may change when these surfaces are in contact with a liquid medium (Tables 1 and 2). Therefore these effects have to be taken into account when performing long-term measurements.

Bacterial adhesion is considered to be an essential step in the pathogenesis of catheter-associated bacteriuria. However, bacterial migration and growth also have to be taken into account. Although bacterial adhesion on to positively charged surfaces is relatively high, the bacterial migration and growth on such surfaces may be decreased as compared to uncharged and negatively charged surfaces. These aspects are currently under investigation.

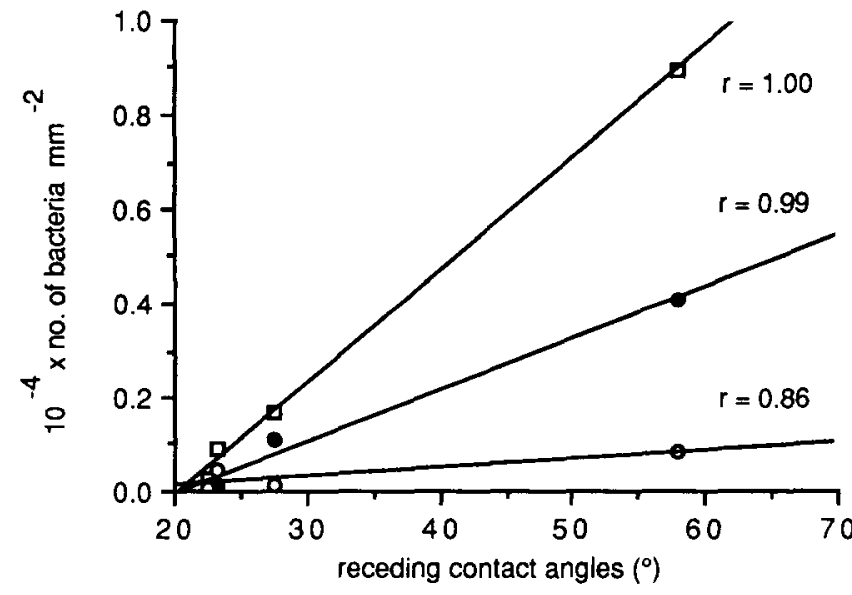

Figure 9 Equilibrium adhesion values against receding contact angles of PMMA PMMA/MAA, PHEMA and PHEMA/MAA. O. $0111 \mathrm{K58}$ - $0157 K: \square, 0161 K$ 


\section{CONCLUSIONS}

- Higher numbers of adherent bacteria are found on positively charged surfaces with positive zeta potentials than on uncharged and negatively charged substrates indicating that electrostatic interactions play an important role in the adhesion process.

- For the polymer surfaces used in this study higher numbers of adherent bacteria are found on polymers with a less negative zeta potential.

- Using polymer surfaces with a negative zeta potential a high number of adherent bacteria is found on to polymers with high receding contact angles.

- Zeta potentials and contact angles of the E.coli strains used have no predictive value for the ability of the bacteria to adhere on to the polymer surfaces used in this study.

\section{ACKNOWLEDGEMENTS}

The authors wish to thank J. Sjollema, H.J. Busscher, H.C. van der Mei and H.M. Uyen for their help with the contact angle measurements, the electrophoresis determinations and the curve fitting procedure. This work was supported by the Medical and Research Foundation of the Netherlands Organization for Scientific Research (NWO).

\section{REFERENCES}

1 Pringle, J.H. and Fletcher, M., Influence of substratum wettability on attachment of fresh water bacteria to solid surfaces, Appl. Envir Microbiol. 1983, 45(3), 811-817

2 Fletcher, M., Attachment of Pseudomonas fluorescens to glass and influence of electrolytes on bacterium-substratum separation distance. J. Bacteriol. 1988, 170(5), 2027-2030

3 Stenström. T.A. Bacterial hydrophobicity, an overall parameter for measurement of adhesion potential to soil particles, Appl. Envir Microbiol. 1989, 55(1), 142-147

4 Stotzky, G., Microbial Adhesion to Surfaces, (Eds R.C.W. Berkeley. J.M. Lynch, J. Melling, P.R. Rutter and B. Vincent) Ellis Horwood Chichester, UK, 1980, pp 231-247

5 Dazzo. F.B., Microbial Adhesion to Surfaces, (Eds R.C.W Berkeley, J.M. Lyrich, J. Melling. P.R. Rutter and B. Vincent) Ellis Horwood Chichester, UK, 1980, pp 311-328

6 Pratt-Terpstra, U.H. Weerkamp. A.H. and Busscher. H.J. The effect of pellicle formation on streptococcal adhesion to human enamel and artificial substrata with various surface free energies. $J$. Dent. Res. $1989,68(3), 463-467$

7 Uyen, M., Busscher, H.J., Weerkamp, A.H. and Arends, J., Surface free energies to oral streptococci and their adhesion to solids. FEMS Microbiol. Lett. 1985, 30, 103-106

8 Weerkamp, A.H., Uyen, H.M. and Busscher, H.J., Effects of zet potential and surface free energy on bacterial adhesion to uncoated and saliva-coated human enamel and dentin. J. Dent. Res. 1988 67(12) 1483-1489

9 Fujioka-Hiral, Y. Akagawa, Y., Minagi, S., Tsuru, H., Miyake, Y. and Suginaka. H., Adherence of Streptococcus mutans to inplant materials. J. Biomed Mater. Res. 1987, 21, 913-920

10 Dankert. J., Hogt, A.H. and Feijen, J.. Biomedical pulymers: bacterid adhesion, colonization and infection. CRC Crit. Rev. Biocompat. 1986 2(3). 219-301

11 Stamm, W.E., Infections related to medical devices, Ann. Int. Med $1978,89,764$

12 Slade, N., Gillespie, W.A., The Urinary Tract and the Catheter, John Wiley, Chichester, UK, 1985, p 12

13 Kunin, C.M., Detection, Prevention and Management of Urinary Tract infertions 4th edn. Lea \& Febiger. Philadelphia, USA, 1987 p 261

14 Jewes, L.A., Gillespie, W.A., Leadbetter A. Myers, B. Simpson, R.A
Stower, M.J. and Viant, A.C., Bacteriuria and bacteriaemia in patients with long-term indwelling catheters - a domicilary study. J. Med. Microbiol. 1988, 26, 61-65

15 Rosenberg, M., Bacterial adherence to hydrocarbons: a useful technique for studying cell surface hydrophobicity. FEMS Microbiol. Lett. 1984, 22, 289-295

16 Hermansson, M., Kjelleberg, S., Korhonen, T.K. and Stenström, T.A., Hydrophobic and electrostatic characterization of surface structures of bacteria and its relevance to an air water interface. Arch. Microbiol. $1982,131,308-312$

17 Busscher, H.J., Weerkamp, A.H., van der Mei, H.C., van Pelt, A.W.J., de Jong, H.P. and Arends, J., Measurement of the surface free energy of bacterial cell surfaces and its relevance for adhesion. Apol. Envir. Microbiol. 1984, 48(5), 980-983

18 Absolom, D.R., Lamberti, F.V., Policova, Z. Zingg. W., van Oss, C.J. and Neumann, A.W., Surface thermodynamics of bacterial adhesion Appl Envir. Microbiol. 1983, 46(1), 90-97

19 Lindahl M. Faris, A. Wadström, T and Hiertén, S., A new test based on 'salting out' to measure relative surface hydrophobicity of bacterial cells. Biochim. Biophys. Acta 1981, 677, 471-476

20 Pedersen, K., Electrostatic interaction chromatography, a method for assaying the relative surface charges of bacteria. FEMS Microbiot. Lett. 1981, 12, 365-367

21 Sherbett, G.V., The Biophysical Characterization of the Cell Surface Academic Press, London, 1978

22 Van Wagenen, R.A. and Andrade, J.D., Flat plate streaming potential investigations: hydrodynamics and electrokinetic equivalency. J. Colloid Interf. Sci. 1980, 76(2), 305-314

23 Dankert, J., Biotyping of Enterobacteriaceae: a method to determine the efficacy of the barrier function of isolation units, in Germfree Research, Academic Press. Inc. New York. 1973, pp 59-67

24 Drskov, I., Orskov. F., Jann, B. and Jann, K., Serology, Chemistry and Genetics of Escherichia coli. Bact. Rev. 1977, 41, 667-710

25 Hogt A.H. Gregonis. D.E.. Andrade J.D. Kim, S.W. Dankert. J. and Feijen, J., Wettabılity and s potentials of a series of methacrylate polymers and copolymers. J. Coll. Interf. Sci. 1985, 106(2). 289-298

26 Gregonis, D.E., Chen, C.M. and Andrade, J.D. Hydroge/s for Medical and Related Applications (Ed. J.D. Andrade) ACS Symp. Series, 31 Amer. Chem. Soc. Washington D.C. 1976

27 Van Damme, H.S., Hogt, A.H. and Feijen, J., Surface mobility and structural transitions of Poly(n-alkyl methacrylates) probed by dynamic contact angle measurements. I. Coll. Intert. Sci. 1986, 114/1). $167-172$

28 Macret, M. and Hild, G. Hydroxyalkyl methacrylates: hydrngel formation based on the radical copolymerization of 2-hydroxy methacrylate and 2,3-dihydroxypropyl methacrylate. Polymer 1982 23(1), 748-753

29 Gregonis, D.E. Russell, G.A and Andrade, J.D. Preparation and properties of stereoregular poly(hydroxyethyl methacrylate) polymers and hydrogels. Polymer 1978, 19, 1279-1284

30 Busscher, H.J. Surface free energies and the adhesion of oral bacteria. Thesis, University of Groningen, 1985

31 Hogt, A.H., Dankent, J. and Feijen, J., Adhesion of coagulase-negatıve staphylococci to methacrylate polymers and copolymers. I Biomed Mater. Res. 1986, 20, 533-515

32 Sjollema, J., Busscher, H.J. and Weerkamp. A.H., Deposition of oral streptococci and polystyrene latices onto glass in a parallel plate flow cell, Biofouling 1988, 1, 101-112

33 Sjollema, J., Busscher, H.J. and Weerkamp, A.H., Experimental approaches for studying adhesion of rnicroorganisms to solid substrata: applications and mass transport, J. Microbiol. Methods $1989,9,79-90$

34 Rutter P.R and Vincent 8 The adhesinn ofmicro-organisms to surfaces: physico-chemical aspects, in Microbial Adhesion to Surfaces. (Eds R.C.M. Berkeley. J.M. Lynch, J. Melling, P.R. Rutter and B. Vincent) Ellis Ilorwood, Chichester, UK, 1980, pp 79-92

35 Van Loosdrecht, M.C.M. Lyklema, J., Norde, W., Schraa, G. and Zehnder, A.J.B., Electrophoretic mobility and hydrophobicitity as a measure to predict the initial steps of bacterial adhesion. Appl. Envir. Microbiol. 1987, 53(8), 1898-1901

36 Hattori, S., Andrade, J.D., Hibbs, J.B., Gregonis, D.E. and King, R.N Fibroblast cell proliferation on charged hydroxyethyl methacrylate copolvmers. J. Coll. Interf. Sci. 1985, 104(1), 72-78

37 Niknvskaya, GN. Gordienko, A.S. and Globa, L.I. Sorption of microorganisms by fibrous materials. Mikrobiologiya 1986, 55(4). 691-694

38 Bowen, B.D., Levine, S. and Epstein, N.E., Fine particle deposition in laminar flow through parallel-plate and cylindrical channels. J. Coll Interf. Sci. 1976, 54(3), 375-390 
39 Harkes, G., Feijen, J. and Dankert, J., Proceedings of the 8th European Conference on Biomaterials, September 7-9, 1989, Heidelberg, FRG submitted for publication

40 Dabros, T. and van der Ven, T.G.M., Kinetics of coating by colloidal particles. J. Coll. Interf. Sci. 1982, 89(1), 232-244

41 Norde, W., Adsorption of biopolymers and its relevance for particle adhesion: a physico-chemical approach, in Bacterial Adhesion and Preventive Dentistry, (Eds J.M. Ten Cate, S.A. Leach and J. Arends) IRL Press, Oxford, UK, 1984, pp 1-17

42 Van Loosdrecht, M.C.M., Lyklema, J., Norde, W., Schraa, G. and Zehnder, A.J.B., The role of bacterial cell wall hydrophobicity in adhesion. Appl. Envir. Microbiol. 1987, 53(8), 1893-1897 